\title{
ナノスケール構造制御によるシリコンの熱電特性の向上
}

\author{
黒㟝＼cjkstart健 ${ }^{1, *}$ エクバル ユスフ 1 宮 崎 宣 $^{1} \quad$ 大 石 佑 治 ${ }^{1}$ \\ 牟田浩明 1 山中伸介 ${ }^{1,2}$
}

\author{
1 大阪大学大学院工学研究科 \\ 2 福井大学附属国際原子力工学研究所
}

J. Japan Inst. Met. Mater. Vol. 79, No. 11 (2015), pp. 569-572

Special Issue on Progresses in the Development of Thermoelectric Materials: New Analyses and New Materials

(C) 2015 The Japan Institute of Metals and Materials

OVERVIEW

\section{Enhancement of Thermoelectric Properties of Silicon by Nanoscale Structure Control}

Ken Kurosaki1,*, Aikebaier Yusufu' ${ }^{1}$, Yoshinobu Miyazaki ${ }^{1}$, Yuji Ohishi ${ }^{1}$, Hiroaki Muta ${ }^{1}$ and Shinsuke Yamanaka1,2

${ }^{1}$ Graduate School of Engineering, Osaka University, Suita 565-0871

${ }^{2}$ Research Institute of Nuclear Engineering, University of Fukui, Tsuruga 914-0055

The effectiveness of thermoelectric (TE) materials which can convert heat gradients into electricity and vice versa is quantified by the dimensionless figure of merit $(Z T)$. Current $\mathrm{TE}$ materials such as $\mathrm{Bi}_{2} \mathrm{Te}_{3}$ and $\mathrm{PbTe}$ whose $Z T$ values are around unity contain highly toxic and/or rare elements, limiting their widespread application. Silicon $(\mathrm{Si})$ is a non-toxic, inexpensive, and earth-abundant element. Although bulk Si exhibits good electrical properties, its lattice thermal conductivity $\left(\kappa_{\text {lat }}\right)$ is high $(>100$ $\mathrm{W} \mathrm{m} \mathrm{m}^{-1} \mathrm{~K}^{-1}$ ), leading to the $Z T$ value of around 0.01 at room temperature. If its $\kappa_{\text {lat }}$ could be lowered while maintaining good electrical properties, Si could be an ideal TE material. These changes can be realized in Si by nanostructuring. Here we review recent results on the enhancement of TE efficiency of Si by nanoscale structure control. Based on the achievements of nanostructured $\mathrm{Si}$ in TEs, we point out some ideas for further enhancement of TE efficiency of Si. [doi:10.2320/jinstmet.JA201501]

(Received April 8, 2015; Accepted May 14, 2015; Published November 1, 2015)

Keywords: thermoelectric, nanostructuring, thermal conductivity, electrical conductivity

\section{1.は じめ に}

全一次エネルギーの約七割を占めるとされる排熱を電気へ と変換する熱電発電が, 近年注目を集めている。一般的な熱 電発電モジュールは, $\mathrm{p}$ 型と $\mathrm{n}$ 型の熱電材料を $\pi$ 型に連続的 に接合し，上下をセラミックス製の板で挟み込んだ形状を有 する．モジュールの上下方向に温度差を設けることで，その 温度差にみあっただけの電気を取り出すことができる. 熱電 発電モジュールのエネルギー変換効率を大きくするために は，モジュールにかかる温度差を大きくすることに加えて， 熱電材料の熱電変換性能指数 $(Z T)$ を向上させることが重要 となる. 代表的な既存熱電材料としては, 性能を発揮する温 度域別に, $\mathrm{Bi}_{2} \mathrm{Te}_{3}$ (室温付近), $\mathrm{PbTe}$ (700 K 付近), $\mathrm{Si}-\mathrm{Ge}$ 合金 $(1000 \mathrm{~K}$ 以上) が挙げられる。これらは, ビスマス $(\mathrm{Bi})$, テルル $(\mathrm{Te})$, 鉛 $(\mathrm{Pb})$, ゲルマニウム $(\mathrm{Ge})$ といった有 毒あるいは希少な元素から構成されている. バルク状の既存 熱電材料の $Z T$ の最大值はおよそ 1 であり，このときの熱電 発電モジュールの変換効率は, モジュールにかかる温度差に

\footnotetext{
* Corresponding author, E-mail: kurosaki@see.eng.osaka-u.ac.jp
}

も依存するが，7〜8\%となる. 自動車や工場からの排熱回 生といった熱電発電の実用化・産業化のためには, 有害·希 少元素を含まず, 室温から $700 \mathrm{~K}$ までの温度域において $Z T$ $>2$ (变換効率 $20 \%$ 相当)を示すような高効率バルク熱電材料 が求められている.

シリコン $(\mathrm{Si})$ は, 毒性が低い, 資源量が豊富, 流通量が多 い, $\mathrm{p}$ 型・ $\mathrm{n}$ 型の制御が容易, 低価格で高品質な材料が入手 可能，デバイス化が容易といった多くの利点を有する．その ため, Si は, 高性能バルク熱電材料になりうる候補の一つ として認識されている，ところが，バルク $\mathrm{Si}$ は非常に高い 格子熱伝導率 $\left(\kappa_{\text {lat }}\right)$ を有し, それゆえ $Z T$ は最大でも 0.2 程 度にしかならない.ノンドープ単結晶 $\mathrm{Si} の \kappa_{\text {lat }}$ は, 室温付 近で約 $140 \mathrm{~W} \mathrm{~m}^{-1} \mathrm{~K}^{-1}$ であり,これは, $\mathrm{Bi}_{2} \mathrm{Te}_{3}$ の $\kappa_{\mathrm{lat}}$ の約 200 倍に相当する. 軽元素, 単純結晶構造, 共有結合という $\mathrm{Si}$ 特有の性質ゆえに，その $\kappa_{\text {lat }}$ は本質的に高い。ところが近 年, $\mathrm{Si}$ をナノスケールで構造制御することで， $\kappa_{\text {lat }}$ を大幅に 低減させ， $Z T$ を飛躍的に向上させたという報告が相次いで なされてきている. 本稿では，これまでに報告されているナ ノ構造 $\mathrm{Si}$ 熱電材料に関する代表的な研究事例を示した後, 現状に基づくいくつかの課題を指摘する. そして, この課題 を解決するために我々が取り組んでいる研究と, これまでに 
得られている成果の概要を紹介する.

\section{2. ナノ構造 Si 熱電材料に関する代表的な研究事例}

\section{1 極微構造 $\mathrm{Si}(\mathrm{Si}$ ナノワイヤー, ナノホール含有 $\mathrm{Si}$ )}

$\mathrm{Si}$ では，フォノンと電子の平均自由行程が大きく異な る.この性質を利用して，Siナノワイヤーに括いて非常に 高い $Z T$ が実現している. 2008 年, Hochbaum ${ }^{1)}$ Boukai ${ }^{2)}$ らよって, Siナノワイヤーの非常に優れた熱電 特性が報告された。彼らは $\mathrm{Si}$ ナノワイヤーの直径等のサイ ズをフォノンの平均自由行程よりも小さくし，キャリアの輸 送を大きく妨げることなくフォノンのみを散乱させることに 成功している. Hochbaum らは, 直径が 50〜 $115 \mathrm{~nm}$ までの $\mathrm{p}$ 型 $\mathrm{Si}$ ナノワイヤーを作製し，それぞれの熱電特性を評価 している. 結果, 直径が $52 \mathrm{~nm}$ の Siナノワイヤーでは, 室 温に敃て $Z T=0.6$ が得られている. 一方, Boukai らは, 幅 $10 \sim 20 \mathrm{~nm}$ ，厚さ $20 \mathrm{~nm}$ の $\mathrm{p}$ 型 $\mathrm{Si}$ ナノワイヤー配列を作 製し，その熱電特性を評価している. 幅 $10 \mathrm{~nm}$ の Si ナノワ イヤー配列は極めて低い熱伝導率 $(\kappa)$ を示すことが報告され ている. その值は $0.76 \pm 0.15 \mathrm{~W} \mathrm{~m}^{-1} \mathrm{~K}^{-1}$ であり,これは, アモルファス $\mathrm{Si}$ の $\kappa\left(1 \mathrm{~W} \mathrm{~m}^{-1} \mathrm{~K}^{-1}\right)$ やバルク $\mathrm{Si}$ の最低熱伝 導率 $\left(0.99 \mathrm{~W} \mathrm{~m}^{-1} \mathrm{~K}^{-1}\right)$ よりも低いものである.このような 低い $\kappa$ ゆえに，200 K に拈いて $Z T=1$ という高い熱電特性 が得られている。

ナノワイヤーのみならず，ナノホールを含有する Si にお いても高い熱電特性が報告されている3-6). 2010 年, 直径が $55 \mathrm{~nm}$ のナノホールが規則的に配列した $\mathrm{p}$ 型 $\mathrm{Si}$ リボン $(1 \sim 3$ $\mu \mathrm{m} \times 20 \sim 50 \mu \mathrm{m})$ で，室温に打いて $Z T=0.4$ が報告されて

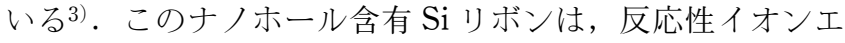
ッチングによって Silicon-on-insulator (SOI) 基板を加工する ことで作製されている. 一方，電子ビームリソグラフィーに よって構築された直径 $11 \sim 16 \mathrm{~nm}$ のナノホールを含有する $\mathrm{Si}$ フィルムにおいて，その 減させた事例が報告されている4 やサイズ，空隙率を最適化した多孔質 Siに打いて，1 $\mathrm{W} \mathrm{m}^{-1} \mathrm{~K}^{-1}$ を下回る $\kappa$ も報告されている5)。しかしなが ら，多孔質 $\mathrm{Si}$ ではキャリア移動度 $(\mu)$ の低下によって電気伝 導率 $(\sigma)$ が低下するという久点がある. 多孔質 $\mathrm{Si}$ 表面に存在 する $\mathrm{SiOH}$ や $\mathrm{SiO}_{x} \mathrm{H}_{y}$ がキャリアを散乱し， $\mu$ の低下を招い ていると考えられている5 る Si に㧍いては，キャリアの散乱を防ぐためにいかにして 表面を清純に保つかが重要な課題であるとされている6).

\section{2 ナノ結晶バルク $\mathrm{Si}$}

前述のように, Siナノワイヤーやナノホール含有 $\mathrm{Si}$ は高 い熱電特性を示す。しかしながら，このような極微構造 $\mathrm{Si}$ は大量生産に向かないという欠点がある．実用化に際して は，バルク体でありながら，その内部は精密に制御されたナ ノ構造となっているようなバルクナノ材料が求められてい る.ここで紹介するナノ結晶バルク Si は, 安価で無毒な高 効率バルクナノ熱電材料の候補の一つとして近年注目を集め ている. 2009 年, Bux 7)らによって $\mathrm{n}$ 型バルクナノ結晶 $\mathrm{Si}$
の熱電特性が報告された. 開発されたナノ結晶 $\mathrm{Si}$ の 温で約 $12 \mathrm{~W} \mathrm{~m}^{-1} \mathrm{~K}^{-1}$ であり， $Z T$ は $1275 \mathrm{~K}$ で 0.7 に達し ている.ナノ結晶 $\mathrm{Si}$ の作製には，ボールミル法と加圧焼結 法を組み合わせた手法が採られている，具体的には，雾囲気 が調整されたグローブボックス内でボールミルにより Si を ナノレベルまで微細化し, 得られたナノ粉末を放電プラズマ 焼結やホットプレスといった手法によって焼結する。これに より，内部組織がナノスケールで精密に制御されたバルク $\mathrm{Si}$ が得られている. ボールミルや加圧焼結の条件を最適化 することで, 熱電特性が最大化するナノ組織の構築が図られ ている．別のグループは，シランガスから気相合成法によっ て合成した $\mathrm{n}$ 型 $\mathrm{Si}$ ナノ粒子を焼結するという手法でナノ結 晶 $\mathrm{Si}$ を作製し, $1223 \mathrm{~K}$ で $Z T=0.5$ という高い熱電特性を 報告している8)。このように作製されたナノ結晶 $\mathrm{Si}$ の は，ナノスケールで大量に導入された結晶粒界におけるフォ ハン散乱を考慮したモデルによってうまく説明されている ${ }^{9)}$.

\section{3. ナノ構造 Si 熱電材料開発における課題}

既往研究にみられるナノ構造 $\mathrm{Si}$ に抢ける高い $Z T$ は, 基 本的には，ナノ構造化によって電気的特性はそれほど劣化す ることなく $\kappa_{\text {lat }}$ のみが低減されたことで達成されている。し かしながら，ナノ構造 $\mathrm{Si}$ を用いた熱電発電モジュールを実 用化していくにあたっては，バルク体に抢いて高い $Z T$ を再 現性良く達成することが求められる．現状得られている高 $Z T$ を示すナノ構造 $\mathrm{Si}$ は, $\mathrm{Si}$ ナノワイヤーに代表される極 微構造 $\mathrm{Si}$ とナノ結晶バルク $\mathrm{Si}$ の二種類がある。前者に関し ては，ナノ構造化による $\mathrm{Si} の Z T$ 向上の原理実証という点 に拉いて，その意義は大きい。一方，後者に関しては，バル ク体を構成するナノ結晶 $\mathrm{Si}$ の粒界におけるキャリア散乱抑 制が，再現性良く高い $Z T$ を得るための重要なポイントとさ れている。しかしながら，ボールミルや気相合成といった手 法でナノ粒子を準備し，それを放電プラズマ焼結やホットプ レスによって焼結するという一般的な手法では，ナノ粒子表 面の酸化や焼結時の粒成長等が生じてしまう。これを解決す る，つまり単純で簡単な手法で，再現性良く，キャリアにと って散乱要因とならないような粒界を持つナノ構造バルク $\mathrm{Si}$ を作製することが，ナノ構造バルク $\mathrm{Si}$ 熱電材料を開発す る上で最も重要な課題とされている．次節では，この課題を 解決するために我々のグループが取り組んでいるいくつかの 研究を紹介する.

\section{4. ナノ構造 $\mathrm{Si}$ 熱電材料に関する我々の取組みと成 果の概要}

\section{$4.1 \mathrm{Si}$-金属シリサイドナノコンポジット薄膜}

キャリアにとって散乱要因とならないような粒界を有する ナノ結晶 $\mathrm{Si}$ を作製する方法の一つとして，アモルファスか らのナノ結晶化がある。アモルファス $\mathrm{Si}$ 薄膜はスパッタリ ングによって簡単に作製できるため，アモルファスを結晶化 することで作製された多結晶 Si は，薄膜卜ランジスタや薄 膜太陽電池等の用途のために盛んに研究されてきた。しかし 
ながら，これらの用途においては結晶粒のサイズは大きい方 が好ましいため，アモルファス $\mathrm{Si}$ をナノスケールで結晶化 させるということはこれまで注目すらされていなかった.

近年, 産業技術総合研究所に抢いて, モリブデン $(\mathrm{Mo})$ を 少量含有するアモルファス $\mathrm{Si}$ を適切な条件下で熱処理する と, Si と Moシリサイドのナノ結晶が同時に晶出し, ナノ 結晶コンポジットが形成されることが見いだされた ${ }^{10,11)}$.

Fig. 1 に, Mo:Si=1:12 の組成 (以下, $\mathrm{MoSi}_{12}$ のように表 記)のスパッタターゲットを用いて作製した Si-Mo シリサイ ドコンポジット薄膜の透過型電子顕微鏡 $(\mathrm{TEM})$ 観察像を示 す．暗い領域は Mo シリサイドであり，明るい領域は Si で ある.この画像から，粒径が $10 \mathrm{~nm}$ 程度の大きさのナノ結 晶が生成していることが確認できる．スパッタターゲットに リン $(\mathrm{P})$ やホウ素 $(\mathrm{B})$ を添加すれば， $\mathrm{n}$ 型と $\mathrm{p}$ 型の双方が作 製可能である。 また，Mo 以外にニッケル $(\mathrm{Ni})$ ，タングステ ン $(\mathrm{W})$ ，クロム $(\mathrm{Cr})$ ，二ニオブ $(\mathrm{Nb})$ のような遷移金属を用い た場合でも，Moの場合と同様にナノ結晶コンポシッッド形 成できる.

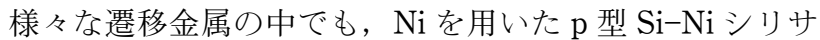
イドナノコンポジット（組成 $\mathrm{NiSi}_{20}$ )が，現在のところ最も高 い熱電特性を示している. 室温において, $\kappa=3.4 \mathrm{~W} \mathrm{~m}^{-1}$ $\mathrm{K}^{-1}, Z T=0.1$ という值が得られている11,12). $\mathrm{NiSi}_{20}$ におい て，電気的特性の温度依存性と室温の $\kappa$ をとと $Z T$ の温 度依存性を推測すると, Fig. 2 のようになる。この值は，

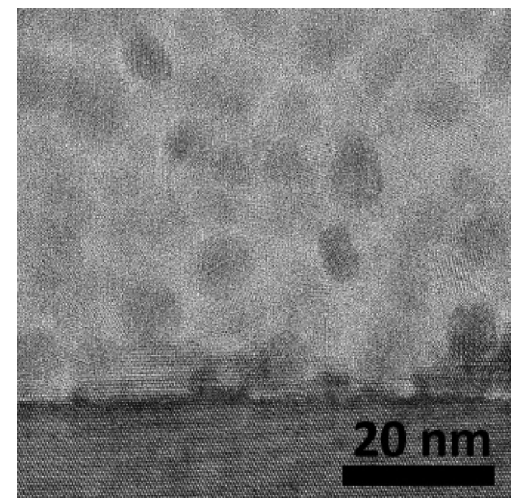

Fig. 1 Cross-sectional TEM image of the $\mathrm{MoSi}_{12}$ film.

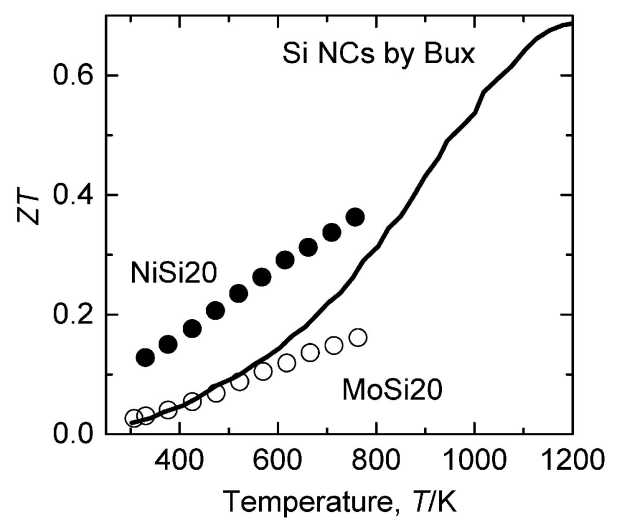

Fig. 2 Temperature-dependence of the $Z T$ of p-type $\mathrm{NiSi}_{20}$ and $\mathrm{MoSi}_{20}$, together with the data of nanostructured Si reported by Bux. ${ }^{7}$
Bux 7)らによって報告されたナノ結晶 $\mathrm{Si}$ の性能を上回って いる，今後は，結晶の配向性制御等を通じて $\sigma$ を向上させ ることで，ZTのさらなる向上を図ることを考えている.

\section{$4.2 \mathrm{Si}$-金属シリサイドナノ共晶液体急冷リボン}

液相からの凝固によって自己組織的にナノ組織を生成させ ることを狙って，Si と金属シリサイドからなる共晶合金の 液体急冷に取り組んでいる， $\mathrm{CrSi}_{2}$ は， $\mathrm{Si}$ と共晶を形成する と同時に，それ自体が比較的高い熱電特性を示す。このため, $\mathrm{Si}$ と $\mathrm{CrSi}_{2}$ からなる複合材料は，熱電材料として高いポテン シャルを有するといえる.アーク溶解で作製した $\mathrm{Cr}_{14.9} \mathrm{Si}_{85.1}$ 共晶合金は, Fig. 3(a)に走査型電子顕微鏡 $(\mathrm{SEM})$ 観察像を 示したとおり，1〜数 $\mu \mathrm{m}$ 程度の共晶組織を形成する. $\mathrm{p}$ 型 キャリア源としてBを $2 \%$ ドープしたものは，室温で 2.9 $\mathrm{mW} \mathrm{m} \mathrm{m}^{-1} \mathrm{~K}^{-2}$ という高い出力因子 $\left(S^{2} \boldsymbol{\sigma}\right)$ を示したが，一方で $\kappa$ も $35 \mathrm{~W} \mathrm{~m}^{-1} \mathrm{~K}^{-1}$ と高い值を示した。この合金を，周速度 $52 \mathrm{~m} \mathrm{~s}^{-1}$ の銅単ロール装置を用いて液体急冷することで, 厚さ $7 \mu \mathrm{m}$ 程度のリボン状の試料を得た. Fig. 3(b)に，リボ ン状試料の自由表面(ロールにあたっていない面)の SEM 観 察像を示す。暗い部分が $\mathrm{Si}$ 相であり, 明るい部分が $\mathrm{CrSi}_{2}$ 相である. 共晶間隔は $20 \sim 40 \mathrm{~nm}$ であり，アーク溶解試料 と比較して百分の一程度にまで組織が微細化されている，液 体急冷リボンの組織では，サイズ分布および組織の方向が揃 ったラメラ構造が特徵的であり，ロールに接した面から自由 表面に向かって一方向凝固している．このリボンの室温での $\kappa$ の值は $12 \mathrm{~W} \mathrm{~m}^{-1} \mathrm{~K}^{-1}$ であり, アーク溶解合金の $\kappa$ の三分 の一程度にまで低減されている. 一方, 出力因子は $2.5 \mathrm{~mW}$ $\mathrm{m}^{-1} \mathrm{~K}^{-2}$ であり, $\mathrm{Si}$ および $\mathrm{CrSi}_{2}$ の高い電気的特性は大き く損なわれていない.ナノスケールでの自己組織的な微細構 造形成の結果，良好な界面特性を有するナノ構造の構築に成 功したといえる。ただし，このコンポジット材料は高温で粒 成長を起こしやすいため，リボン状試料からバルク試料をい

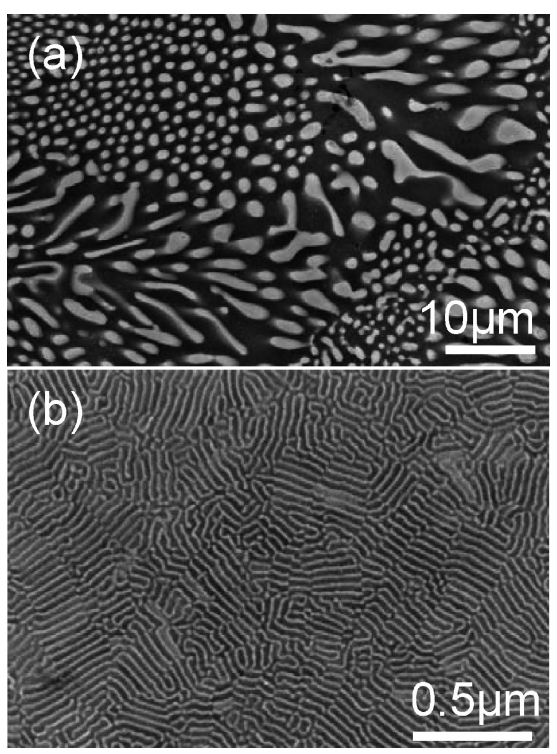

Fig. 3 SEM image of $\mathrm{Cr}_{14.9} \mathrm{Si}_{85,1}$ eutectic alloy prepared by (a) arc melting and (b) melt spinning at the rolling rate of $52 \mathrm{~m} \mathrm{~s}^{-1}$ 


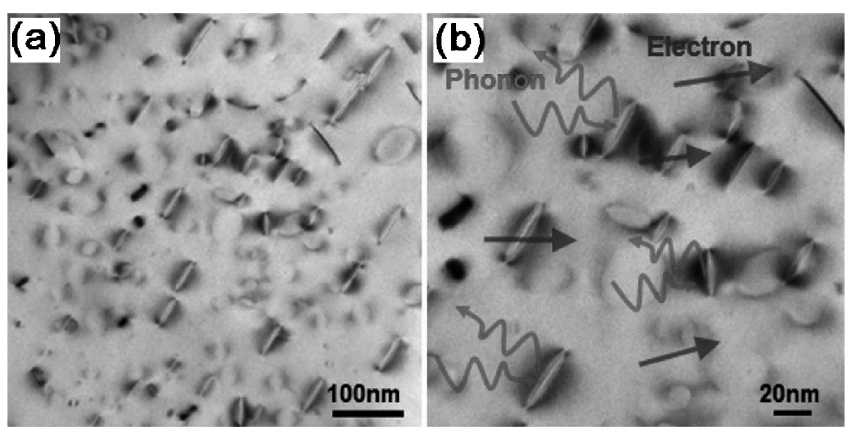

Fig. 4 (a) TEM image of a bulk $\mathrm{Si}_{97} \mathrm{Ge}_{3} \mathrm{P}_{3}$ sample, showing $\mathrm{P}$-rich nanoscale inclusions with the sizes ranging $5-100 \mathrm{~nm}$ naturally-precipitate in the Si matrix. (b) The nanoscale inclusions scatter effectively heat-carrying phonons but do not scatter carriers.

かにして作製するかが今後の課題とされている。

\section{3 ナノ析出物自己形成バルク $\mathrm{Si}$}

熱電材料の母相中にナノスケールの第二相を析出させ，母 相と析出物間に形成された界面でフォノンを散乱させる試み が近年注目されている. PbTe や PbS といった鉛含有カル コゲナイドに抢いて実際にこの現象が実証されており， $\kappa_{\text {lat }}$ の十分な低減とそれに伴う $Z T$ の大幅な向上が確認されてい る. ごく最近, 著者らのグループは, $\mathrm{Ge}$ を少量含有する $\mathrm{Si}$ においてこれと同様のメカニズムで $Z T$ を向上させることに 成功した.アーク溶解と放電プラズマ焼結といった簡便で汎 用的な手法で， $\mathrm{P}$ を高ドープしたバルク $\mathrm{Si}$ 中に， 5〜100 $\mathrm{nm}$ 程度の $\mathrm{P}$ リッチの第二相が析出しているような組織 (Fig. 4)を作り出した. このPリッチ析出相には, サイズが 約 $5 \mathrm{~nm}$ の球状のものと, サイズが約 $20 \mathrm{~nm}$ の板状のものの 二種類があり, 前者はコヒーレントに, 後者はセミコヒーレ ントに，それぞれマトリックス相と接触していることが高分 解能 TEM 観察により確認されている.このようなコヒーレ ント，セミコヒーレント接合により，電子の輸送は妨げられ ることなくフォノンのみが効果的に散乱され, 結果 $Z T$ の大 幅な増大が達成されている，今回最適化された組成は仕达久 組成で $\mathrm{Si}_{97} \mathrm{Ge}_{3} \mathrm{P}_{3}$ であり，ZTの最大值は $1050 \mathrm{~K}$ で $Z T=$ 0.6 である13).

\section{5.おわりに}

以上，様々なナノ構造 $\mathrm{Si}$ の熱電特性をレビューしてき た.ここで示したように，いくつかのナノ構造 Siにおいて は確かに高い $Z T$ が達成されている. また，ごく最近では， $\mathrm{Si}$ の極小なナノドット結晶を結晶方位をそろえて連結する ことで， $\sigma$ の徳化を抑えながら，バルク $\mathrm{Si}$ の約二百分の一 という世界最小の $\kappa$ が達成されてもいる14). しかしなが ら, 熱電発電の実用化の目安である $Z T=1$ がバルク体にお
いて再現性良く達成できているかというと，そうでもない。 ただし，最近は，ZTだけでなく材料の毒性やコスト，製造 の容易さ等も勘案して総合的に熱電材料の性能を評価しよう とする試みもある15)。こういった点からみると，バルクナ ノ Si は極めて有望な熱電材料になりうるといえる. 特に, 4.3 節で示したように, 簡便・汎用的な手法で再現性良く比 較的高い $Z T$ が得られることもわかってきており, 今後, こ れに関連した研究の発展が期待できる. また, 単にナノ構造 化だけでは $Z T$ の向上にも限界があることは確かなので，ナ ノ構造化に付随するあるいは意図的に追加する別の効果を取 り入れることが重要であるといえる．著者らのグループで は, 変調ドープ16)やエネルギーフィルタリング効果17)に着 目し,これらの現象をナノ構造 Si で実証すべく, 研究をす すめている.

本研究を遂行するにあたり，(国研)科学技術振興機構 ALCA-先端的低炭素化技術開発, 科学研究費補助金 (25289220), 大阪大学未来知創造プログラムより研究費の 一部を助成いただいた。ここに謝意を表する。

文 献

1) A. I. Hochbaum, R. Chen, R. D. Delgado, W. Liang, E. C. Garnett, M. Najarian, A. Majumdar and P. Yang: Nature 451 (2008) 163.

2) A. I. Boukai, Y. Bunimovich, J. Tahir-Kheli, J.-K. Yu, W. A. Goddard III and J. R. Heath: Nature $\mathbf{4 5 1}(2008) 168$.

3) J. Tang, H.-T. Wang, D. H. Lee, M. Fardy, Z. Huo, T. P. Russell and P. Yang: Nano Lett. 10(2010) 4279.

4) J.-K. Yu, S. Mitrovic, D. Tham, J. Varghese and J. R. Heath: Nature Nanotechnol. 5(2010) 718.

5) G. Korotcenkov and B. K. Cho: Crit. Rev. Solid State $\mathbf{3 5}(2010)$ 153.

6) J. de Boor, D. S. Kim, X. Ao, M. Becker, N. F. Hinshe, I. Mertig, P. Zahn and V. Schmidt: Appl. Phys. A 107 (2012) 789

7) S. K. Bux, R. G. Blair, P. K. Gogna, H. Lee, G. Chen, M. S. Dresselhaus, R. B. Kaner and J.-P. Fleurial: Adv. Funct. Mater. 19(2009) 2445.

8) G. Schierning, R. Theissmann, N. Stein, N. Petermann, A. Becker, M. Engenhorst, V. Kessler, M. Geller, A. Beckel, H Wiggers and R. Schmechel: J. Appl. Phys. 110(2011) 113515.

9) T. Suzuki, Y. Ohishi, K. Kurosaki, H. Muta and S. Yamanaka: Appl. Phys. Express 5 (2012) 081302.

10) Y. Ohishi, K. Kurosaki, T. Suzuki, H. Muta, S. Yamanaka, N. Uchida, T. Tada and T. Kanayama: Thin Solid Films 534 (2013) 238.

11) Y. Ohishi, Y. Miyazaki, H. Muta, K. Kurosaki, S. Yamanaka, N. Uchida and T. Tada: J. Electron. Mater. 44(2015) 2074.

12) N. Uchida, T. Tada, Y. Ohishi, Y. Miyazaki, K. Kurosaki and S. Yamanaka: J. Appl. Phys. 114(2013) 134311.

13) A. Yusufu, K. Kurosaki, Y. Miyazaki, M. Ishimaru, A. Kosuga, Y. Ohishi, H. Muta and S. Yamanaka: Nanoscale 6(2014) 13921.

14) Y. Nakamura, M. Isogawa, T. Ueda, S. Yamasaka, H. Matsui, J. Kikkawa, S. Ikeuchi, T. Oyake, T. Hori, J. Shiomi and A. Sakai: Nano Energy 12(2015) 845.

15) S. K. Yee, S. LeBlanc, K. E. Goodson and C. Dames: Energy Environ. Sci. 6(2013) 2561.

16) R. Dingle, H. L. Störmer, A. C. Gossard and W. Wiegmann: Appl. Phys. Lett. 33(1978) 665.

17) S. V. Faleev and F. Leonard: Phys. Rev. B 77 (2008) 214304. 